\title{
ROLE OF DIAGNOSTIC LAPAROSCOPY IN CHRONIC PELVIC PAIN AND ITS COMPARISON WITH TVS
}

\author{
Naruka Nisha1 , Acharya Veenaㄹ, Mishra Hemant ${ }^{3}$, Meena Ashok ${ }^{4}$ \\ ${ }_{1}^{1}$ Associate Professor, Department of Obstetrics and Gynaecology, Mahatma Gandhi Medical College and Hospital, Jaipur. \\ 2Professor, Department of Obstetrics and Gynaecology, Mahatma Gandhi Medical College and Hospital, Jaipur. \\ 3 Professor, Department of Radiology, Mahatma Gandhi Medical College and Hospital, Jaipur. \\ ${ }_{4}^{4}$ Resident, Department of Obstetrics and Gynaecology, Mahatma Gandhi Medical College and Hospital, Jaipur.
}

ABSTRACT
BACKGROUND
Chronic pain is a common gynaecological problem. The causes of CPP are numerous like gynaecological causes or non-
gynaecological causes, but CPP is very difficult to diagnose. So, aim of the study is to evaluate the use of TVS based on hard and soft
markers in detection of pelvic pathology in women with chronic pelvic pain and compare it with laparoscopy for knowing
sensitivity and specificity.

\section{MATERIALS AND METHODS}

Study was hospital based. Total number of women taken were 220, who were attending regular outdoor in Mahatma Gandhi Medical College and Hospital, Jaipur with history of Chronic Pelvic Pain (CPP). Age group was 18 - 50 years.

\section{RESULTS}

This study was carried out in Mahatma Gandhi Medical College and Hospital, Jaipur during October 2010 to October 2012. There was a statistically significant association between TVS based hard markers and laparoscopic findings. Out of 120 cases of abnormal scan of TVS 116 were abnormal on laparoscopy, thereby showing PPV of 93.55\%. TVS based hard markers had higher Specificity (73.33\%) and Sensitivity (61.05\%).

\section{CONCLUSION}

Though laparoscopy is the gold standard for diagnosis of chronic pelvic pain, it is concluded that TVS with use of hard and soft tissue markers is very useful in diagnosis of Chronic Pelvic Pain.

\section{KEYWORDS}

CPP- Chronic Pelvic Pain, TVS- Transvaginal Sonography, Sensitivity, Specificity, Hard Markers, Soft Markers and Laparoscopy.

HOW TO CITE THIS ARTICLE: Nisha N, Veena A, Hemant M, et al. Role of diagnostic laparoscopy in chronic pelvic pain and its comparison with TVS. J. Evolution Med. Dent. Sci. 2018;7(10):1243-1246, DOI: 10.14260/jemds/2018/283

\section{BACKGROUND}

Chronic pelvic pain is a common gynaecological problem. ACOG defined chronic pelvic pain in 2004 as "noncyclic pain of 6 or more months' duration that localises to the anatomic pelvis, anterior abdominal wall at or below the umbilicus and lumbosacral back."[1]

The RCOG (2005) has given the definition of chronic pelvic pain as intermittent or constant pain in lower abdomen or pelvis of at least 6 months' duration, not occurring exclusively with menstruation or intercourse and not associated with pregnancy.[2]

An estimated prevalence of chronic pelvic pain in UK is $38 / 1000$ women aged $15-73$ years and monthly prevalence rates range from $18.2 / 1000$ women in 15 - 20 years old to $27.6 / 1000$ women older than 60 years. ${ }^{[3]}$

Chronic pelvic pain is an affiliation of women during the peak of their productive years at a mean age of $28.6 \pm 7.0$ years (Reiter and Gambone 1990).[4]

'Financial or Other Competing Interest': None.

Submission 19-01-2018, Peer Review 13-02-2018,

Acceptance 21-02-2018, Published 05-03-2018.

Corresponding Author:

Dr. Acharya Veena,

\#712, Modal Town,

Malviya Nagar

Jaipur.

E-mail: krs3012@gmail.com

DOI: $10.14260 /$ jemds $/ 2018 / 283$

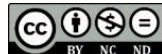

\section{Causes of Chronic Pelvic Pain}

Gynaecological causes may be uterine - adenomyosis, leiomyoma, endometrial or cervical polyp, IUCD, chronic endometritis and cervical stenosis.

\section{The Non-Gynaecological causes may be-}

1. Urinary tract.

2. Gastrointestinal.

3. Musculoskeletal.

4. Psychological factors.

Conventionally, an ultrasound will report the presence or absence of structural abnormality called hard markers, such as ovarian cyst or hydrosalpinx.

However, more information can be obtained about the state of pelvis by its degree of ovarian mobility, pelvic tenderness as well as presence of loculated peritoneal fluid in the pelvis. These pelvic findings are termed as 'soft markers.' $[5]$

Tenderness-guided transvaginal sonography showed the highest sensitivity of $91 \%$ in detection of Endometriosis of vaginal walls. For endometriosis of rectovaginal septum, the sensitivity was $74 \%[6]$ TVS predicts endometriomata, POD obliteration and bowel infiltration with a sensitivity of $90 \%,[7]$ 90.9\% ${ }^{[8]}$ and $90.7 \%$ (Picketty et al, 2009). ${ }^{[9]}$ It is estimated that about $40 \%$ of laparoscopies done for CPP,[10] endometriosis is diagnosed in $33 \%$, adhesive disease in $24 \%$ and no visible pathology in $35 \%$ of patients.[11]

Aim of this study is to evaluate the use of TVS based on hard and soft markers in detection of pelvic pathology in 
haemorrhagic cysts were noted in $8.2 \%$ cases. Ovarian mobility was restricted in $56 \%$ cases. Site specific pelvic tenderness was seen in $77 \%$ cases. 140 (70\%) patients had loculated peritoneal fluid on TVS.

\begin{tabular}{|c|c|c|}
\hline Structure & Findings & Number $(n=110)$ \\
\hline \multirow{6}{*}{ Uterus } & Normal & 120 \\
\hline & Congestion & 32 \\
\hline & Endometriosis & 28 \\
\hline & Tubercles & 28 \\
\hline & Adhesions & 16 \\
\hline & Myoma & 6 \\
\hline \multirow{9}{*}{ Adnexa } & Normal & 60 \\
\hline & Congestion & 6 \\
\hline & $\begin{array}{l}\text { Endometriosis } \\
\text { (Cysts) }\end{array}$ & 34 \\
\hline & Adhesions & 100 \\
\hline & $\begin{array}{l}\text { Oedematous and } \\
\text { Thickened }\end{array}$ & 22 \\
\hline & $\begin{array}{l}\text { Dilated and Beaded } \\
\text { Tubes }\end{array}$ & 14 \\
\hline & Tubercles on Tubes & 16 \\
\hline & TO Mass & 28 \\
\hline & Hydrosalpinx & 20 \\
\hline \multirow{5}{*}{ Pouch of Douglas } & Normal & 100 \\
\hline & Adhesions & 90 \\
\hline & Endometriosis & 30 \\
\hline & Scarring & 8 \\
\hline & Fluid & 150 \\
\hline \multirow{4}{*}{ Peritoneum } & Normal & 140 \\
\hline & Adhesions & 60 \\
\hline & Endometriosis & 8 \\
\hline & Tubercles & 8 \\
\hline \multicolumn{3}{|c|}{$\begin{array}{c}\text { Table 4. Laparoscopy Finding in Chronic Pelvic Pain in Our } \\
\text { Study }\end{array}$} \\
\hline
\end{tabular}

\begin{tabular}{|c|c|c|c|c|c|c|}
\hline \multirow[b]{2}{*}{ 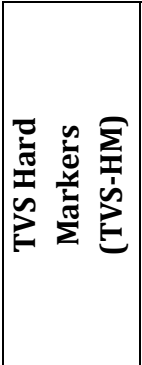 } & \multirow{2}{*}{ 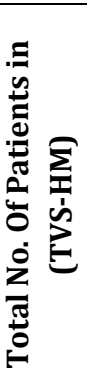 } & \multicolumn{2}{|c|}{$\begin{array}{l}\text { Laparoscopic } \\
\text { Findings }\end{array}$} & \multirow{2}{*}{$\begin{array}{c}\text { Sensitivity } \\
61.05 \%\end{array}$} & \multirow{2}{*}{$\begin{array}{c}\text { Specificity } \\
\\
73.33 \%\end{array}$} & \multirow{3}{*}{$\begin{array}{l}2 \\
\vdots \\
0 \\
0 \\
3 \\
3 \\
2\end{array}$} \\
\hline & & 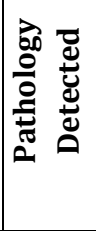 & 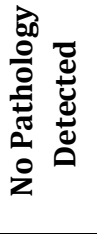 & & & \\
\hline $\begin{array}{l}\text { Pathology } \\
\text { detected }\end{array}$ & 120 & 116 & 8 & & & \\
\hline $\begin{array}{c}\text { No } \\
\text { pathology } \\
\text { detected }\end{array}$ & 100 & 74 & 22 & & & \\
\hline \multicolumn{7}{|c|}{$\begin{array}{c}\text { Table 5. Correlation between TVS, Hard Markers and } \\
\text { Laparoscopic Findings in Chronic Pelvic Pain }\end{array}$} \\
\hline
\end{tabular}

Above table demonstrates a statistically significant association between TVS based hard markers and laparoscopic findings. Of the 120 cases that showed an abnormal scan of TVS based hard markers 116 were abnormal on laparoscopy, thereby showing a positive predictive value of
93.55\%. It was observed that TVS-based hard markers had higher specificity (73.33\%) than sensitivity (61.05\%).

\begin{tabular}{|c|c|c|c|c|c|c|}
\hline \multirow[b]{2}{*}{$\begin{array}{l}\text { TVS Hard } \\
\text { Markers } \\
\text { (TVS-HM) }\end{array}$} & \multirow{2}{*}{\begin{tabular}{|c|} 
Total \\
No. of \\
Patients \\
in \\
(TVS-HM)
\end{tabular}} & \multicolumn{2}{|c|}{ Laparoscopic Findings } & \multirow{4}{*}{ 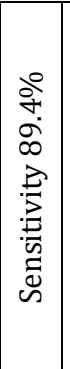 } & \multirow{4}{*}{ 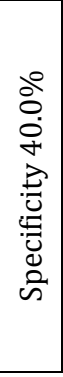 } & \multirow{4}{*}{ 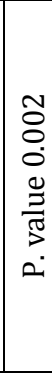 } \\
\hline & & $\begin{array}{l}\text { Pathology } \\
\text { Detected }\end{array}$ & \begin{tabular}{|c} 
No \\
Pathology \\
Detected
\end{tabular} & & & \\
\hline $\begin{array}{c}\text { Pathology } \\
\text { detected }\end{array}$ & 188 & 170 & 18 & & & \\
\hline $\begin{array}{c}\text { No } \\
\text { pathology } \\
\text { detected }\end{array}$ & 32 & 20 & 12 & & & \\
\hline Table 6. C & & & & & & \\
\hline
\end{tabular}

TVS based soft markers were more sensitive (89.4\%) than specific (40\%).

\section{DISCUSSION}

The study was conducted on two hundred and twenty patients with history of chronic pelvic pain in gynae OPD in Mahatma Gandhi Medical College. In our study, the correlation between clinical examination findings and laparoscopic findings was not found to be statistically significant, applying the chi-square test ( $\mathrm{p}$ value- 0.394 ).

\section{Transvaginal Sonography- Hard Markers}

In our study, a statistically significant association $(p=0.012)$ was seen between hard markers and laparoscopy indicating that hard markers on transvaginal sonography can be used reliably in the detection of pelvic pathology.

\section{Transvaginal Sonography Soft Markers}

In the present study "the soft markers" analysed on TVS were site specific pelvic tenderness, ovarian mobility and loculated peritoneal fluid. In our study, TVS based soft markers showed Sensitivity of $89.47 \%$, Specificity of $40.00 \%$ and PPV of 90.43\%.

In our study, the TVS based soft markers and laparoscopy showed a statistically significant association with a $p$ value of 0.002 .

\section{Laparoscopy}

In our study laparoscopic examination was normal in $13.69 \%$ of the patients, whereas remaining $86.36 \%$ showed some pelvic pathology. The common pathology detected were adhesions (54.55\%) and endometriosis (25.45\%).

In our study, prevalence of adhesions in patients with CPP were $54.55 \%$. A large number of studies have been undertaken regarding prevalence of adhesions in patients with CPP observed by Kresch et al (1984) in 38\%.

\section{CONCLUSION}

Laparoscopy is a gold standard for the diagnosis of chronic pelvic pain. From the study, it has been concluded that by TVS with use of hard and soft tissue markers is very useful for diagnosis of chronic pelvic pain with high sensitivity and specificity. TVS based soft markers were having sensitivity of $89.4 \%$ than specificity of $40.0 \%$. The TVS showed site specific pelvic tenderness in diagnosis of chronic pelvic pain, which cannot be detected by laparoscopy. Laparoscopy requires expert laparoscopist, anaesthesia, OT and moreover it is an invasive procedure which many a times is not appropriate for all the patients in a day-to-day practice. We can use TVS as a primary screening tool for the diagnosis of chronic pelvic pain. 


\section{REFERENCES}

[1] ACOG Committee on Practice Bulletins--Gynecology. ACOG Practice Bulletin No. 51. Chronic pelvic pain. Obstet Gynaecol 2004;103(3):589-605.

[2] RCOG Guideline No. 41. The initial management of chronic pelvic pain. April 2005.

[3] Zondervan KT, Yudkin PL, Vessey MP, et al. Prevalence and incidence of chronic pelvic pain in primary care: evidence from a national general practice detabase. $\mathrm{Br}$ J Obstet Gynaecol 1999;106(11):1149-55.

[4] Reiter RC, Gambone JC. Demographic and historic variables in women with idiopathic chronic pelvic pain. Obstet Gynaecol 1990;75(3 Pt 1):428-32.

[5] Okaro E, Condous G, Khalid A, et al. The use of ultrasound based 'soft markers' for the prediction of pelvic pathology in women with chronic pelvic paincan we reduce the need for laparoscopy? Br J Obstet Gynecol 2006;113(3):251-6.

[6] Gao X, Outley J, Botteman M, et al. Economic burden of endometriosis. Fertil Steril 2006;86(6):1561-72.
[7] Ballweg ML. Impact of endometriosis on women's health: comparative historical data show that the earlier the onset, the more severe the disease. Best Pract Res Clin Obstet Gynecol 2004;18(2):201-18.

[8] Duffy DM, diZerega GS. Adhesion controversies: pelvic pain as a cause of adhesions, crystalloids on preventing them. J Reprod Med 1996;41(1):19-26.

[9] Lafferty HW, Angioli R, Rudolph J, et al. Ovarian remnant syndrome: experience at Jackson Memorial Hospital, University of Miami, 1985 through 1993. Am J Obstet Gynecol 1996;174(2):641-5.

[10] Jamieson DJ, Steege JF. The prevalence of dysmenorrhoea, dyspareunia, pelvic pain, and irritable bowel syndrome in primary care practices. Obstet Gynaecol 1996;87(1):55-8.

[11] Howard FM. The role of laparoscopy in chronic pelvic pain: promise and pitfalls. Obstet Gynecol Surv 1993;48(6):357-87. 